\title{
Agency and Vulnerability: Reconfiguring the Female Characters in Chimamanda Adichie's Love Stories
}

\author{
*Elizabeth O. BEN-IHEANACHO
}

\begin{abstract}
Agency and vulnerability are integral factors in the feminist reconceptualization of the self. Consequently, they are significant concepts in gender identity. This article recognizes the pressures on an individualôs agency and vulnerability to societal containment as constant interplay that accounts for creative dimensions and responses intensified within a love relationship. It locates agency and vulnerability as mutually inclusive within the philosophical nexus of self-actualization and self-empowerment that preaches a focus on the self; being a tranformative, defining lifestyle that helps an individual achieveself-discovery, purpose and gender progression. Whereas the feminist philosophy is the theoretical framework, the approach to this story is critical interpretative discourse to AdichieôsAmericanahand ñTransition to Glory,ò her short story in an anthology entitled African Love Stories. This paper examines the implications of agency and vulnerability in these love stories as narratives in class, position and power within the battlefield of affairs of the heart. It submits that vulnerability and agency should not be seen merely from the prism of societal and cultural power structure that maintain patriarchal status quo but as subtle but significant factors aiding and abetting the winning party in the female contest for the heart strings of a man.

Keywords: Agency, Vulnerability, Love Story, Gender Identity, Chimamanda Adichie.

\section{Introduction}

Vulnerability, as argued by Sarah Lubrano is an intrinsic requirement for loving another human being who is essentially a part yet apart from the woman; be that ñotherò her child or the one
\end{abstract}

\footnotetext{
*Elizabeth O. BEN-IHEANACHO of the Research \& Documentation Department,
}

National Council for Arts and Culture, Abuja Email: lizatease@yahoo.com 
she permits intimacy with herself (1). It is the inevitable source of laying oneself bare to another, hence, a source of exposure to pains and betrayal; of which the man-woman-love experience is fraught. On the positive side, vulnerability exposes us to a full recognition of our frail humanity and connectedness to others around us, in the full glory of sharing the pleasures and pains of living life. Consequently, vulnerability is a key concept to understanding feminist agency in the sense of activism; of taking action not as an end in itself but as genuine recognition between autonomy and cultural structures of containment and accepted protocol. In this vein, when a manôs secret lover; otherwise referred to in this paper as his ñside chickò, confronts his wife (also referred to as the ñmadam of the houseò) the unfolding narrative must be situated within the context of vulnerability as its force connects both women to recognize that living life and loving exposes women to the harm of being cheated on by the man they share intimacy with. That singular act of his cheating ties the two women to each other. Agency and individual autonomy requires that each woman lives true to herself; make her decisions, explores her choices in order to live a life of purpose and direction. This is the core of social relationship and responsiveness that propels the dynamics of the love tangle explored by Ozioma in Adichieôs ñTransition to Glory.ò

Agency, on the other hand, be it individual or collective, is the heart of all radical (political) projects, being a decisive break from the norm. For feminists, it connotes a deliberate deconstruction of the bonds that hold back self-actualization and gender affirmation. It is an individual expression of the enchantment with the self as an autonomous being. When feminists talk of agency, therefore, they refer to how societal and cultural power structures affect a womanôs ability to act, take decisions and make choices (Law 1). The capacity of every human to act as an agent is personal to that individual (Wilson, George and Shpall Samuel 2012). The moral vulnerability question lies in the weight of considerations for the outcome of a particular action taken. Moral vulnerability demands that obligations are acknowledged, and responsibilities assigned. Sometimes the dilemma of appropriate response demands care and caution; at other times 
aggression is apt. Hence, Oziomaôs near obsessed questioning of her place in Aghaôs life, the value of her work as an on-air personality and its appreciation by the society she served and sought to impact and mould, is akin to a search for psychological security, an autonomous demand for acknowledgment and relevance in order to validate her agency.

Value judgement, therefore, may hamper agency or propel it towards self-regulation, self-reflection and proactiveness. Further, stereotyped response to agency/self-living typifies the paradox that celebrates individual freedom while expecting necessary obedience to the universal containment laws; adultery/cheating being the case here where a man is encouraged to marry one wife and be loyal to her all the days of their lives until death do them part. In Ifemelu (Americanah) and Ozioma (ñTransition to Gloryò) Adichie created characters whose very personalities carry the seeds of deviance, rebellion and unsocialised quirkiness that subvert and disrupt all cultural protocol. Ifemelu and Ozioma are goal-directed, intentional agents; both are aware and actively engaging with their issues as well as the goals that their activities are aimed at realizing. Ifemelu returns to Nigeria with every intention of rekindling her teenage romance with Obinze (Americanah17) while Ozioma gets enmeshed with her married lover fully conscious of her decision was not a happenstance (ñTransition to Gloryò 46). Indeed, agency as moral theory in ethics can be said to have its counterpane in ontological vulnerability; where vulnerability focuses on the susceptibility of particular persons or groups to specific harm or threat.

Vulnerability and agency are not opposites but mutually important and necessary to the full experience of human life (Mackenzie 41). Both contribute to a flourishing life, especially as not everyone can be autonomous all through life; some are dependent by nature or made dependent by what life serves. Equally, as humans, we are all susceptible to being vulnerable and to being used as mere means by others (Formosa 103). Hence, exercising oneôs autonomy requires recognition by others to whom we have been classified as ñoutsidersò, ñmarginalò, ñperipheralò, and ñon-existentò by the cultural and social structures. From this perspective, Oziomaố assertion of her individuality and agency is 
self-conflicting. As a ñside chickò, she chaffs at the social restraints and does not accommodate the status quo as does Aunty Uju in Americanahwho was contented to be the ñinvisible otherò in the Generalôs love life. Rather, Ozioma seeks recognition of her being and a validation of her significance in her loverôs life. This insistence on recognition is in itself a moral dilemma that opens a window to contrary notions of love. Set within the invasion of gender territorial struggle of women in love with same man, it must be observed that Oziomaôs agency is not the self-compelling destructive brand that betrays the bonds of friendship in the quest for a manôs love as evidenced in Sulasô betrayal of her long life best friend, Nel, by having an affair with Nelôs husband in her misguided notion of husband sharing as an extension of the womenôs friendship (Morrison 125). Neither is it a quest for a soulôs completion and mythical soul mate undertaken by Ifemelu, in her determination to reclaim Obinze even if her victory upsets the entire fabric of his own life and family setting. Rather, Ozioma is propelled by a personal reconstruction of the place of her agency in the larger community of her radio audience, her loverôs family and even the betrayed wifeôs consciousness.

\section{The Love Story and the Nigerian Literary Corpus}

As we have observed elsewhere, the highways and byways of the notion of the love story as romantic love and the ideas associated with it as well as its modes of expression are all part of the cultural memorabilia resulting from colonization (Ben-Iheanacho 97). While prescribed school texts fed students imagination on Western popular ideas of love, television, and pulp magazines helped to fuel the fevered imagination of the emergent first generation educated elite as well as their poorer, not-so-literate imitators, popular Western female writers such s Denise Robins, Barbara Cartland, among others, published by such outlets as Mills and Boons helped to champion the stock formulae of Western romance that were street reading materials mostly for women. In these syrupy love stories, boy met girl, they fell in love and as a cardinal principle of romance fiction, are able to surmount all obstacles in the way of their love to live happily ever after. These stories were mostly 
beloved by female readers and across age and class. The street culture popularity of these novels has not been reciprocated by a corresponding corpus of African writers of romantic fiction genre.

Obiechina proffers a sociological explanation to this: ñthe mutual attraction of people of opposite sex, and their integration through mutual affection and total preoccupation with this mutual relationship, the state which is recognized as óbeing in loveò, receives much functional emphasis within the Western cultural tradition and hardly any emphasis at all within the African cultural tradition until the contact between Africa and the West altered the situationò (32). To bear out Obiechinâ̂ assertion, NwapaốEfuruwhich is Africaôs first novel by an African female and arguably the love story of the heroine, Efuru and the love of her life, Adidua, is deflected in its romantic genre pursuit by Adiduâ̂́ waywardness and Efuruố barrenness. Achebeôs Things Fall Apart, celebrated for its portrayal of the masculine values of its Igbo patriarchal society setting, ironically contains one of Africâ̂ greatest love stories, the story of OgbuefiNdulue and his soul mate, Ozoemena. However, Achiebeôs treatment of this great love (53-54) categorized it an oddity, an aberration best consigned to the collection of strange stories of strange times; a mere minor observation in the more serious issues of life, an unmanly chapter in a warriorôs book of life:

ñThe things that happen these days are very strangeò

ñWhat happened?ò asked Okonkwo

ñDo you know OgbuefiNdulue?ò Ofoede asked

ñOgbuefiNdulue of Ire villageô Okonkwo and Obierka said together

ñHe died this morningô said Ofiedu

ñThat is not strange. He was the oldest main in Ire,ôsaid Obieuka

ñYou are right,ôOfoedu agreed. But you ought to ask why the drum has not been beaten to tell Umuofia of his deathô 
ñWhy?ôasked Obierika and Okonkwo together ñThat is the strange part of it. You know his first wife who walks with a stick?ô

ñYes, she is called Ozoemenaò

ñThat is soô said Ofoedu. ñOzoemena was, as you know, too old to attend to Ndudue during his illness. His younger wives did that.

When he died this morning, one of these women went to Ozoemenaôs hut and told her. She rose from her mat, took her stick and walked over to the obi. She knelt on her knees and hands at the threshold and called her husband, who was laid on the mat. ñOgbuefiNdulueQ̂ she called three times and went back to her hut. When the youngest wife went to call her again to be present at the washing of the body, she found her lying on the mat, deadò.

ñThat is very strange indeedô said Okonkwo. ñThey will put off Ndulueôs funeral until his wife has been buriedô

óThat is why the drum has not been beaten to tell Umuofiaô

d́t was always said that Ndulue and Ozoemena had one mindô said Obierika. đ́ remember when I was a young boy there was a song about them. He could not do anything without telling herô

đ́ did not know thatô said Okonkwo. ñ thought he was a strong man in his youthò.

ñHe was indeedô said Ofoedu.

Okonkwo shook his head doubtfully

ñHe led Umuofia to war in those daysô said Obierika. (Achebe 53-54) 
In her analysis of the dearth of love stories among contemporary African writers, Aidoo blamed it on a certain disconnection between African literature and its oral and written roots. She elucidated that following the collision of civilization, Western mediators in African cultural manifestations failed to recognize African love stories because it did not easily fall into the stock Western formulae. Her list of contemporary African love stories include NgugiwaThiongoốThe River Between, Mariama Baôs So Long A Letter, Ama Ata AidooốChanges, Lewis NkosiôsThe Mating Birds, BuchiEmechetaôsThe Joys of Motherhood and Grace OgotôsRain. However, she acknowledges that this genre is beset with a peculiar problem of literary invisibility $\tilde{n} .$. in the modern African novel as a love story, the love story is never revealed as such. Because it is completely subsumed under ñthe more important social and political issuesò which the modern African writer (thinks she/he) has to deal with: incompetent leadership and their betrayal of their peoples, the antics of áhe lumpenmilitariatò (....), complete economic collapse, racial tensions, outmoded traditional thought and practices.... ò (Aidoo x-xi).

AdichieôAmericanahand ñTransition to Gloryò are interesting in not only the twist they bring to the accepted plot of the classic love story inherited from Western notions which chronicles the emotional intimacy of one man and one woman, both emotionally unencumbered and, therefore, free to pursue their attachment to each other to a logical conclusion; often marriage. Instead, in Americanah, Adichie is iconoclastic in her narrative of the love story between Ifemelu and Obinze who meet as secondary school unintended love match, become soul mates in spite of their class differences, are separated by the quest for greener pastures in America and are reunited by Ifemeluôs determination to staunch the drift of her life by anchoring it to the captain of her soul, Obinze, now married and a doting father to his daughter. In óTransition to Gloryò Ozioma is a young lover to her married sugar daddy, Agha in a ñsituationshipò where there are no lies about the manôs marital status and the ñdead-ended-nessò of their affair. It is the creative dimensions explored in this inversion of the literary convention in Adichieôs love stories that we now turn to. 
Adichie's Love Stories as Narratives in Class, Position and Power

As earlier noted, Adichieôs love stories exhibit a twist in the plot by introducing the married man as the object of desire. This unexpected bump on the road to happily-ever-after elicits the stock response of shutting down the relationship in injured dignity as the lady love must be most unwilling to share love; where love is popularized as the connection of two souls until death do them part. Consequently, to love a married man is taboo in such contrived, Western pulp image of love, neither is a married person expected to love another in this monogamistôs emotional paradise. Important, too, this brand of love does not condone a woman violating the sanctity of another womanôs happy home and emotional marital territory. In Americanah, Adichie creates Aunty Uju, the passively unassuming dismantler of this assumption who knows her lover is happily and visibly married but acquiesces to playing the role of áhe other womanô with aplomb, quiet dignity and milking it for all maternal benefits accruing to her and her extended family. In the same vein, Ozioma, the main female character in ñTransition to Gloryò is also a side chick but the direct personality opposite to Aunty Uju. Both are well educated, selfempowered, career -focused, young women; Uju is a medical doctor while Ozioma is a radio broadcaster. While Uju is a fully conscious agent deliberate in her choice of a married army general as lover and father of her son outside wedlock, she maintains the status quo and unwritten code concerning side chicks: silent, publicly unacknowledged, never intruding into the socially accepted public and domestic image of the lover, a peripheral being on the margins of the loverôs life.

Clearly, this idea of love is a power-based relationship where the lover holds the aces; the side chick is the recipient of and basks in the benefits of the celebrity popularity. In such a óituationshipô the man of power is the subject, the absolute; his side chick is ñthe otherò especially to the legal wife and madam of the house. Indeed, the side chick is the non-object, non-person, and a mere body hardly worth the arrogant glance from madam.

Compare, however, the generalôs wifeôs angst against Uju at the demise of the general and Aghaôs wifeôs unruffled disdain for an 
intrusive Ozioma who violates this culturally endorsed emotional environment and entanglement power structure. Ozioma, on the flip side of the personality spectrum, chaffs against the societal restraints imposed on the side chick. She is more questioning and probing of these conventions and ñsituationshipò protocol, seeking her place in the off-limits sphere of her loverôs life; consumed about philosophical musings on the right and wrong of their relationship.

She knew he never missed listening to her show- and she wondered now if his wife listened to it, too, since it was on at the time when he would be at breakfast. His youngest child, Emeka, might be there as well as his daughter Nnennaya....And perhaps the first daughter, Adanma, would drive by from her flat, on her way to work, and join the family for breakfast and they would all listen to her show.... She wanted to ask if he ever consumed with the same thoughts as she was: thoughts about right and need. (ñTransition to Gloryò 38-39)

Unlike Uju, Ozioma is not obligated to Agha, her wellheeled lover for her financial survival though she is not averse to accepting gifts and even the possibility of him renting a flat for her in the highbrow Abebe Court (36). Aghaôs power over her was in effortlessly consigning her to the ñother mattersò category of his well manicured life; a leash she strains against. Hence, her confrontation of Aghaôs wife and madam of the house, to force herself beyond the limits into reckoning; to validate her place in their shared manôs life beyond sneaky meetings in hotel rooms and the anonymous streets of London. Therefore, Oziomaôs act must be located within the philosophy of the self: a quest for her meaning beyond the marginal; a reach out to her right to love and be loved back, to be acknowledged as a factor that mattered. It is also a take back bid, to wrestle power from those that had rendered the side chick as an anonymous chapter in a loverôs wife. 
In Americanah, Obinze and Ifemeluôs love story is steeped in class snobbery, social integration and structural inequalities. From the outset, Obinze, the only child of a middle class, selfaware female Professor and Ifemelu who was from the wrong side of the working class, were not supposed to become a couple:

The gods, the hovering deities who gave and took teenage loves, had decided that Obinze would go out with Ginika. Obinze was the new boy, a fine boy.... He was quickly admitted into the clan of swaggering, carelessly cool mates, the Big Guys.... The second most popular girl was Ginika, Ifemeluôs close friend. Ginika did not go abroad often and so did not have the air of away as Yinka did but she had caramel skin and wavy hair... And so, it was the natural order that the gods should match Obinze and Ginika. (Americanah 71-72)

As their love story deepened in intimacy, Ifemelu achieves acceptance by Obinzeôs maverick mother but the love birds are separated by Ifemeluôs scholarship to study in America where she gains polish, celebrity status as a blogger and the socially enviable status as "Americanah" when she returns to Nigeria in search of self-definition in spite of the glamour and urbane sophistication of her American success story. For Obinze, however, his óAmericanamaniaò ended with him being deported from United Kingdom for incomplete papers. Back in Lagos, his refined pedigree stands him out among the hustlers for the favour of the wheeler-dealer Chief whose connections make and unmake millionaires. Admitted into the Lagos Big Boys Club by the grace of Chief, Obinze marries a socially befitting wife that complements his status. His idyll is disrupted with the return of his lost love, Ifemelu back to Nigeria. A now self-assured, all-conquering 
returnee, Ifemeluôs unconscious quest is to find herself a husband as she casts the enchanting veil of teenage love with its syrupy and heady sweetness of insatiate youthful lust to launch a reclamation bid for Obinzeô love, upstaging Kosi, his wife and taking back her man. ñî̂m also going back to Nigeria to see my manò, Ifemelu said, surprising herself. My man. How easy it has to lie to strangers, to create with strangers the versions of our lives that we have imaginedò (Americanah 29). This Freudian slip certainly laid bare the truth of the battle ahead that the truly married madam-ofthe-house had no warning enough to prepare for.

As a diasporan returnee, Ifemelu is technically on the outside of her Nigerian home, looking in. A culturally displaced hybrid, she is at the same time a dislocated ñawayanò seeking reentrance and re-admittance to a life that could have been hers. The anchor to her rudderless ship was not just marriage, but to a man that belonged to the social status her American experience bequeathed her a sense of entitlement to. Obinze, with his affluent ease and cash baked certainty that came with hobnobbing with the moneyed class and foreign accents, was the ticket. That they had an intense emotional past was icing on the cake. And love, they say, conquered all.

Our final consideration in our thesis of love as power struggle is to examine the reaction of the wife of the philandering man in these love stories under study. They exhibit vulnerability on account of being cheated on but often, their agency to react is emasculated and denied by social imposition on their role as the madams-of-the-house. As had been opined earlier in this article, agency can be denied when cultural power structures are such that a character is not able to act or make choices for itself. This implies that there is a higher authority that acquiesces to an individualôs power to act (Law 1). Such ñhigher authorityò could be the environment and statutes (coded or un-coded) governing social interaction or even a personality and authority figure within the matrix of the love enchantment. Within this interpretative framework, the madams-of-the-house cheated on are often presumed by the cheating partners, to be in the dark about their affairs. Often, they act along, knowing but pretending ignorance, 
feigning a carefree, heart unbroken demeanour; therefore, victims too of expressing their true disposition and acting out their choices. For the generalôs wife, she delegates her enraged foot soldiers and relatives to unleash terror on Uju only after the generalôs death released her from a sense of helplessness and powerlessness. The ensuing ñpower showòby the squad of ñdo-goodersò and defenders of the injured rights of the madam-of-the-house and the protectors of the rights of a violated side chick is an epic clash of agency of enraged females:

There was banging on the gate. Two men and three women, relatives of the General, had bullied Adamu to open the gate and now stood at the front door, shouting. ñUju! Pack your things and get out now! Give us the car keys! $\hat{\omega}$ One of the women was skeletal, agitated and red- eyed and as she shouted ñCommon harlot! God forbid that you will touch our brotherôs property! Prostitute! You will never live in peace in this Lagos!òï she pulled her headscarf from her head and tied it tightly around her waist, in preparation for a fight. At first, Aunty Uju said nothing starring at them, standing still at the door. Then she asked them to leave in a voice hoarse from tears, but the relativesô shouting intensified, and so Aunty Uju turned to go back indoors. ñOkay, donâ go,ò she said. ñJust stay there. Stay there while I go and call my boys from the coumy barracks.ò (Americanah 106)

Obinzeôs wifeôs agency is denied precisely by her knowledge of her husbandố affair and her personal disposition to such a relationship and an expectation to act on such knowledge as beneath her class and pedigree. Acculturation by her upbringing and socially ingrained responses to such a situation, restrains her from any contact with the ñother woman,ò ñthe outsiderò consequently, she concentrates her cold fury on her husband. 
ñObinze, this is a family,ò Kosi said. ñWe have a child. She needs you. I need you. We have to keep this family together.ò She was kneeling and begging him not to leave and he wished she would be furious instead.

ñKosi, I love another woman. I hate to hurt you like this and é òñtôs not about another woman, Obinze, ñKosi said, rising to her feet, her voice steeling, and her eyes hardening. ñitôs about keeping this family together! You took a vow before God. I took a vow before God. I am a good wife. We have a marriage. Do you think you can just destroy this family because your old girlfriend came into town? Do you know what it means to be a responsible father? You have a child downstairs! What you do today can ruin her life and make her damaged until the day she dies! And all because your old girlfriend came back from America? Because you have had acrobatic sex that reminded you of your time in the university?ò Obinze backed away. So she knewé He loathed Kosi, for knowing all this time and pretending she didnâ know, and for the sludge of humiliation it left in his stomach. He had been keeping a secret that was not even a secret. (Americanah 523-524)

Clearly, Kosiôs agency is restrained not by an inability to act, but by her acquiescence to the higher authority of her moral superiority as wife, to the lusts and yearnings of an errant husband for a mere side chick, a concubine, the other woman. It is this subscription to the rules of engagement with the other woman that Didi, Aghaôs wife in ó́r ransition to Gloryò also rigidly holds on to when the rambunctious Ozioma violates the terms of engagement by visiting the grieving woman in her own home. In this clash of 
self, class and pedigree, Oziomaôs brush with cultural structures left her bruised for it.

Didi sits down. ñHow dare you come here? How dare you?ò

The question does not surprise Ozioma but Didiôs calmness does. And she realizes how like Agha Didi is, the same calm smile, the same civil coating over their body movements. The same incredible control. They were both cultured, worldly people, Agha and DidiOzioma feels a strange helplessness, a weightlessness: she is sure she would float away if she jumped up now, if her feet left the ground.

ñDid he tell you about me?ò She asks.

Didi is silent for a while. ñHe was perfect, my husband. He was perfect at lying, he was perfect at everything.ò A pause, and for the first time, there is a sneer on Didiôs face, or may be, the sneer has always been there and lets itself out now. óNo, my dear, of course he didnâ tell me about you.ô

ñThen how did you know?ò

ñI assume you expect me to answer your question.ò Didi shifts on her seat and slowly crosses her legs. ñWhat I find interesting is that my daughter Adanma is a year older than youò. Didi is smiling, and even though it is that familiar civil smile, Ozioma sees the rage in it, in the stretch of lip over teeth. (ñTransition to Gloryò 48- 49)

\section{Conclusion}

In our discourse on vulnerability and agency as significant factors in the feminist philosophy of the self, we domiciled our field of analysis on the most intimate of human relationship $\ddot{i}$ the love affair. Further, we explored a taboo cultural formation to the 
Western concept of love and romance, popularized and dominant in contemporary literacy experience through culture contact and colonial footprints on African nuances. This is the triangle of the philandering husband, his betrayed wife and madam-of-the-house and the strange woman or the cheating partner. Our discourse has shown that each individual is susceptible to vulnerability. Equally, each expresses agency differently or chooses to deny and defer agency. That very act of self-denial is itself a choice and an expression of individual autonomy. Finally, it was found that these individuals are all aware, enlightened and determinants of their choices, subverting conventions in most cases and actively creating their own responses to situations. They each bear out the ontological disposition that ultimate freedom of the individual consists in recognizing the compatibility or otherwise of subjective desires to objective structures as well as the tools they have equipped themselves with to negotiate the conflicts that must necessarily arise within their cultural environments, successfully.

\author{
Works Cited \\ Achebe, Chinua. Things Fall Apart. London, Heinemann, \\ 2008.Print. \\ Adichie, Chimamanda. ñTransition to Glory.òAfrican Love \\ Stories.Ed. Ama A. Aidoo. \\ Oxfordshire: Ayebia Clarke Publishing Ltd., 2006. 34-49. Print. \\ Adichie, Chimamanda. Americanah.Lagos: Kachifo Ltd., 2013. \\ Print. \\ Aidoo, Ama A. ñntroduction.ò African Love Stories.Ed. Ama A. \\ Aidoo. Oxfordshire: Ayebia \\ Clarke Publishing Ltd., 2006.vii - xi. Print. \\ Ben-Iheanacho, Elizabeth O. ñLove in the Time of Boko Haram- \\ Deconstructing Othuake \\ Omniabhorsô Odufa as Romance Fiction.òLapiai Research in \\ Humanities 4.1 (2017): 96-109. Print.
}


Formosa, Paul. ñThe Role of Vulnerability in Kantian Ethics.òVulnerability: New Ethics and

Feminist Philosophy.Ed. Mackenzie Catriona et al. New York: Oxford University Press, 2014. Web. 4 March 2017 $<$ http://ndpr.nd.edu/new/>.

Law, Evin P. ñWhat does it Mean when Feminists Talk about Agency?òWeb. 4 March

$2017<$ https://www.quora.com/What-does-it-mean-when-feministstalk-about- agency>.

Lubrano, Sarah S. Vulnerability as a Key to Feminism. Web. 5 Dec.2016<https://manifestamagazine.com/2013/02/15/vuln erability-as-a-key-to-feminism/>.

Macknezie, Catriona. ñThe Importance of Relational Autonomy and Capabilities for an Ethics of Vulnerability.ò Vulnerability: New Ethics and Feminist Philosophy. Ed. Mackenzie Catriona et al., New York: Oxford University Press, 2014. Web. 4 March 2017<http://scholar.google.com/scholar_url?url=http://eltal ondeaquiles.pucp.edu.pe/wpcontent/uploads/2016/09/Studies-in-Feminist-PhilosophyCatriona-Mackenzie- $>$.

Morrison, Toni. Sula. New York: Plume Penguin Group, 1982.Print.

Nwapa, Flora. Efuru. London, Heinemann, 1966. Print Obeichina, Emmanuel. An African Popular Literature: A Case Study of Onitsha Market Pamphlets. Cambridge: University Press, 1973. Print.

Wilson, George and Shpall Samuel.ñAction. ÒStanford Encyclopedia of Philosophy.Web. 8 March $2017<$ https://plato.stanford.edu/entries/action/notes.html $>$. 